\title{
Cracking the political code: the case of e-participa- tion in Colombia
}

\section{César Abusleme, Public Systems Centre, University of Chile}

cabusleme@um.uchile.cl

Abstract: Theory says that, in normal circumstances, politicians do not have many incentives to make the policy process more democratic, and that these political dynamics may be embedded into the enactment of technology. This work will try to determine if this holds true in the case of Urna de Cristal, a Colombian e-participation scheme. The nation-wide projects implemented by this programme in 2017 are analysed using three sets of political criteria-inclusion, participation, and deliberation-drawn from an evaluation framework of centralized cross-platform approaches to social media exploitation by government agencies (Ferro et al. 2013). The evidence suggests that the enactment of Urna de Cristal's projects reflected the Colombian government's intention of preventing the policy process from becoming more participatory and deliberative. Some data suggests the government tried to render this process more inclusive. Further research on e-participation should consider the political complexity of technology enactment in the public sector.

Keywords: e-participation, technology enactment, digital government, politics of the digital

Acknowledgement: this article is based on a research essay submitted to the course "Information Systems for the Public Sector: Digital Government and Service Innovation" from the London School of Economics and Political Science (LSE) in 2018. My postgradues studies in LSE were funded by the 2017 Becas Chile Scholarship Scheme run by Chile's Research and Development National Agency (ANID).

\section{Introduction}

Information and Communication Technologies (ICTs) are deemed as a very powerful tool to further democratic values such as public transparency, government accountability and openness, as well as citizen collaboration and participation (Becker 1998; Bertot et al., 2010; Kim et al., 2007; Obama, 2009). Nonetheless, the first scholarly works on digital government focused on achieving the horizontal integration of services across government (Layne \& Lee, 2001) and, above all, on increasing public sector efficiency (Heeks, 1999). It was later that authors such as West (2004) considered that the final stage of e-government development should include the creation of an "interactive democracy" and 
"a range of accountability measures". Far beyond this recognition of the strong connection between furthering democratic principles and the evolution of digital government, Weerakkody et al. (2011) coined the concept of "transformational government" to refer to a whole new tier of technologyenabled change in government in which different public-sector objectives are met, including efficiency, transparency, accountability and citizen centricity. Accordingly, a "first wave" of e-government-related changes would have streamlined government processes and improved public service delivery (Dunleavy et al., 2006), whereas a "second wave" would have facilitated co-production of services, and enabled citizen online testimonials and evaluations, as well as open book government and citizen surveillance (Dunleavy \& Margetts, 2013). Nevertheless, it should be noticed that there is evidence of e-participation being in the political agenda long before this second wave took place (OECD, 2001; Scottish Parliament, 1998; Whyte \& Macintosh, 2001).

In this context, the central governments of a number of developing and developed countries have decided to run e-participation schemes, this is, technology-enabled projects that, at least on paper, pretend to render the policy process more inclusive, participatory, or deliberative (UN, 2016). These public programmes would be a great example of the close relationship between technology and democracy since e-participation would enable people to be better informed of how decisions are made (inclusion), express their opinions in the process (participation), and even influence the policy output (deliberation). This, of course, is more complicated in practice. As we will see below, the literature suggests that politicians do not often have many personal incentives to allow people to partake in policy decisions. Those in office have probably invested time and money to hold their privileged positions within the political system and, therefore, they would not be willing to give their power away to the people. Moreover, the e-government scholarship argues that the enactment of technology is affected by technical, organisational, social, and political factors, and that these factors may also be embedded into it. Therefore, even though governments formally run e-participation projects, the technologies involved in the implementation of these schemes might be enacted in a way in which it is unlikely for them to render the policy process more inclusive, participatory, or deliberative.

This work will try to test if this holds true in the case of Urna de Cristal (literally "Crystal Ballot Box"), an e-participation scheme run by the Colombian government since 2010. The analysis is carried out following a very simple plan. To begin with, the next section presents a brief review of the literature dealing with the political and technological complexity of e-participation, with a particular emphasis on the political intentions of the (executive) government authorities implementing such projects. Then, the third section outlines the data and methods used to conduct the case study, while the fourth presents and discusses its results. The final section concludes.

\section{Literature review}

\subsection{What is e-participation?}

Participation has traditionally been considered one of the main three components of open government. When Barack Obama (2009), more than a decade ago, issued his famous Memorandum on 
Transparency and Open Government, instructed the U.S. Office of Management and Budget (OMB) to pass a directive following three key principles: transparency, collaboration and participation. This Directive ended up declaring that participation is needed for governments to embrace the ideas and expertise of citizens and, therefore, to make better policies (Orszag, 2009). This idea of participation would imply that the "middlemen" that intermediate between the government and citizens -representatives in Congress, for instance-are not always necessary and that citizens should be empowered to create a (more) direct and open democracy (Fung et al., 2013). Nonetheless, since participation, and especially e-participation, may also be part of collaboration and transparency measures, Abu-Shanab (2015) have proposed replacing Obama's three foundational principles with four new open government dimensions: i) transparency, ii) information accountability, iii) collaboration and iv) empowerment.

The academic definitions of e-participation have been faithful to the political conceptualisation of participation. Medaglia (2012, p.346), for instance, considers, following Macintosh (2004), that eparticipation implies "the use of ICT to support democratic decision-making (...) enabling opportunities for consultation and dialogue between government and citizens". Similarly, Sanford \& Rose (2007, p.408) suggest that e-participation would enable a technology-mediated interaction between the civil social sphere, on the one hand, and either the formal politics sphere or the administration sphere, on the other hand. These definitions have been challenged by Susha and Grönlund (2012). While they admit that e-participation is strongly linked to the broader e-government (and open government) scholarship, they draw a strict distinction between e-participation and e-democracy. Eparticipation may be used for achieving undemocratic or neutral goals, and its scope and methods would span beyond politics - it is not necessarily a political issue since it may be related to public service delivery or even to private-sector practices. Somewhat aware of this critique, the United Nations (UN) conceive e-participation "as the process of engaging citizens through ICTs in policy, decision making, and service design and delivery in order to make it participatory, inclusive, and deliberative" (2016, p.49; emphasis added). These distinctions are, however, only theoretical simplifications that help students to better understand the areas of government impacted by e-participation. In the real world, these dimensions-policy and decision making, service delivery-are more complex and intertwined. Just consider the case of an e-voting system, a public service delivered by the administration sphere to facilitate participation in democratic processes.

Despite these concerns, the study of e-participation remains politically biased. Different literature reviews (Sanford \& Rose, 2007; Sæbø et al., 2008) show that e-participation is usually related either to political deliberation or decision-making processes. In this context, Susha and Grönlund (2012) argue that most scholars take for granted that the goal of e-participation is to create a direct democracy - the Internet would be deemed as the panacea for creating a powerful public sphere where anyone is entitled to participate (Chadwick, 2008). This normative assumption, however, will be seriously scrutinised in the next section. 


\subsection{Why would government authorities further e-participation?}

It's very difficult to deny that new technologies and digital innovations have transformed government. Twenty-five years ago, Osborne and Gaebler (1993) managed to write a bestseller on reinventing government with almost no mention of information and technology (Heeks, 1999). Today, that would be simply impossible. At least since the nineties, ICTs have been broadly and actively embraced by almost every government office in developed and developing countries (Dawes, 2008; Margetts, 2003), digital technologies have ostensibly changed administrative procedures (Hood 2000; Vintar 1995), the investment in technological solutions has become an important part of the public budget (Heeks \& Davies, 1999; Margetts, 2003), and digital strategies have played a key role in transformational schemes (Gore, 1993; Heeks, 1999; Heeks \& Davies, 1999; UK Cabinet Office, 1999, 2017). From an external viewpoint, all these transformations have contributed to changing the form in which governments interact with citizens and stakeholders (Hood \& Margetts 2007; Wong \& Welch 2004). For many, the government is not just a group of people anymore, but also a "platform" (Bracken, 2015; O'Reilly, 2011). As a matter of fact, nowadays a person looking for public information or applying for a government benefit is more likely to interact, at least in early stages, with a webpage than with an actual civil servant.

This, however, does not necessarily mean that information and technology have radically transformed government. Most scholars agree, based on empirical evidence, that ICTs have only produced limited and incremental change in public-sector structures (Dawes, 2008; Dwivedi et al.,2012; Luna-Reyes \& Gil-García, 2014; Margetts, 1999, 2003; Scholl, 2005; Norris \& Moon 2005, West, 2004). Accordingly, technology would not bring about change by itself but as the result of an interplay between different factors. Put differently, technology would not directly and deterministically cause a transformation of government, but would enable this change to happen (Buffat, 2015; Weerakkody et al., 2011). Then, technology-enabled change would be favoured or deterred by technical, political, social, institutional and organisational influences (Cordella \& Iannacci 2011; Dwivedi et al., 2012; Fountain, 2001; Heeks \& Davies, 1999).

From a political perspective, digital government projects may also be studied through the lens of the power relationships in which they are designed and deployed. In this line, the power networks that Foucault (1980) called dispositifs might be helpful to explore the relevance of these interactions. Indeed, following Foucault's ideas, "power does not manifest itself as an institution but rather as continuously functioning nets of relationships that form into chains with each other" (Eriksson, 2005), as shown by the study of power-knowledge structures in the digitalisation of government and public administration in Estonia (Björklund, 2016) and the establishment of Citizen Service Centres in Greece (Introna et al., 2009). Moreover, from an action-network-theory perspective, "power is always in relation to something or someone else" and thus allowing citizens into policy making would not only change the network structure but also, and maybe more importantly, the ability of those in control of the process to enact their power (Heeks \& Stanforth, 2007).

In this context, it's clear that the analysis of e-participation cannot overlook the political dynamics that would enable technology to bring about its potential benefits. The literature has suggested that the match between e-participation and more democracy is largely oblivious to the fact that political 
authorities do not have enough personal incentives to promote more inclusive, participatory or deliberative policy processes (Chadwick, 2008; Fung et al., 2013). Put differently, it is unlikely for politicians that have spent time, money and (maybe) labour on reaching a certain position to give back their power to the people without obtaining anything in exchange. In this line, Chadwick (2011) shows that one of the factors explaining the failure of an e-participation project in a U.S. local government was the "political ambivalence" of its councillors, this is, the decoupling between formal and actual political support. Similarly, but with different results, Ahn and Bretschneider (2011) have demonstrated that the political motivations of the mayor of Gangnam-gu were vital to the success of the e-participation strategy of this Korean district.

Nonetheless, scholars usually correlate the success of e-participation projects to user preferences, attitudes or relations with technology (Zolotov et al., 2018), functionality (Zheng, 2017), institutional conditions (Chadwick, 2011), and organisational structures (Zheng et al., 2014). Thus, the importance of political interests and personal incentives has been largely disregarded by the e-participation literature (Panopoulou et al., 2014) and cross-national studies (Girish et al., 2014). This apolitical approach towards its success factors is contradictory with the above mentioned understanding of e-participation as a political question closely connected to democracy (see Section 2.1.). However, it fits quite well with the ideas of Fountain (2001) who famously drew a distinction between objective technology (e.g. e-mail) and enacted technology (e.g. the actual use of e-mail). For her, the enactment of technology would be determined by organisational forms and institutional arrangements, as the "cultural assumptions" of an organisation about ICT (Bellamy \& Taylor, 1998). Orlikowski (2000) had previously admitted that the same technology may be enacted differently depending on both internal and external factors. She even acknowledged that technology was not necessarily neutral nor "objective" but downplayed the role of content previously inscribed into ICTs since it would be later altered and manipulated by human actions.

This socio-technical perspective is fairly successful in explaining why the same technology is enacted in different fashions in different settings. Nevertheless, it seems to overlook the fact that ICTs are not only affected by political dynamics - they may also be intrinsically political (Winner, 1999). Indeed, Cordella \& Iannacci (2010) have shown that there is no such thing as "objective" technology since technical, organisational and political variables are embedded into them. Put differently, technology is shaped and reshaped by political dynamics. In this line, it has been proposed that the enactment of ICT in the public sector would embody the political intentions of the elite in office and, therefore, it is unlikely for it to produce radical change in power structures (Dawes, 2008; Holliday, 2001; Hood, 2006; Hood \& Margetts, 2007; Kraemer \& King 1986; Rethemeyer, 2007). Then, those who foresee that blockchain technology will transform the centralised government system into a "networked governance" in which power is not fully concentrated in any institution (Keyser, 2017; Ølnes et al., 2017) would be as misguided as those who thought the e-mail would alter the hierarchical structures of public bureaucracies (Meijer, 2008).

e-Participation technologies should be examined through the lens of these academic concerns and the UN (2016) have provided a very good starting point. They have developed a framework that distinguishes three broad levels or categories in which ICTs can be enacted in the context of e-participation schemes. The first level is e-information. This would be the "safer" one for politicians -in 
this case, the government would restrict the use of technology to informing people about their work and achievements, and therefore it is hard to distinguish from transparency measures (e.g., open data portals, press releases, etc.). At a second level known as e-consultation, citizens would not only receive official information but also would have the opportunity to express their opinions using technological resources. The third level is more ambitious that both e-information and e-consultation. Indeed, the so-called e-decision-making level would imply that citizens are entitled to influence policymaking. At this point it is important to remember that, according to the literature, in normal circumstances, politicians do not have many incentives to share their powers with third parties (citizens, the Congress, journalists) and, therefore it would be unlikely for politicians to adopt e-decision-making strategies. The $2016 \mathrm{UN}$ survey on e-government confirms this expectation - just 38 out of 193 member states declared that at least one of their e-consultation initiatives have ended up influencing a policy decision. This categorisation is really useful since it helps to easily group different e-participation schemes under the umbrella of just three well-established clusters, but it should be noticed that it is also a simplification - the actual enactment of technology is more complex and unique in each case.

In addition to the general UN framework, there are also more technology-tailored categorisations that may be helpful to test the idea of politics being embedded into ICTs. Mergel (2013a; 2013b), for instance, argues that governments usually adopt three different strategies with regards to the enactment of Social Network Sites (SNS): the push strategy, the pull strategy and the network strategy. The push strategy refers to the use of SNS as just an extension of regular online tools, this is, as if every government post on social media was just a press release or a public announcement. On a pull strategy more interaction with citizens is allowed in order to lead them to visiting the official government website on which more (official) information would be found. Finally, governments would also develop network strategies in which public officials would use SNS to create a space of effective interaction between them and their constituencies - people would be listened to and their opinions would be taken into account in policymaking. According to Fontaine's (2001) ideas, the enactment of SNS and, therefore, the use of any of the strategies described by Mergerl would only depend on institutional conditions and organisational arrangements. Conversely, following Cordella \& Ianacci's (2010) argument, the e-government policy should be also included in the formula. Then, if we consider that politicians do not have many incentives to give their powers away by making the policy process more participatory (Fung et al., 2013), we should expect that the push and pull strategies will be more likely to be adopted by the government than network strategies. The work of Mossberger, $\mathrm{Wu}$ and Crawford (2013) have confirmed that this was exactly what happened in the deployment of social media strategies by the local governments of Seattle, Louisville, and Chicago. This work will try to figure out if this also holds true in the case of Colombia's Urna de Cristal.

All of this does not mean that the potential of information and technology to enable the improvement of democracy should be discarded altogether. Without modern technologies, the implementation of open data portals, e-voting systems and e-participation programmes would be simply unthinkable. Thus, from a deterministic perspective, ICTs have been capable of expanding the set of tools available to the government for improving democracy. However, the literature suggests that it is not certain that these new tools will be used to effectively enhance democracy, which may be very disappointing from a normative viewpoint. Indeed, some authors are convinced that information 
and technology may transform government in a rather antidemocratic fashion (Hood 2006; Hood \& Margetts 2007; van de Donk et al., 1995). New technologies would allow governments to control and conduct surveillance over people more effectively than ever before, threatening the exercise of the fundamental rights to privacy and freedom. In this context, big data technologies would allow governments to carry out surveillance using "easier, cheaper, and more useful" methods (Mayer-Schönberger \& Cukier 2013, p.315). This poses a real risk to people's rights since harvesting information widens the asymmetries of power between government and citizens (Gandy, 1989; Solove 2001).

ICTs would be able to produce change in different directions, depending on a variety of political, cultural, organisational, and even budgetary factors. Actually, the same technologies that may help totalitarian governments to exert their surveillance powers over people may also facilitate the establishment of a data-driven public sector in which citizen needs are more easily taken into account (OECD, 2014). At this point, it should be remembered that this literature review only deals with the political intentions of the government authorities enacting technology - if the scope of the study was broadened to the entire political system, we would likely find more positive news regarding the role of citizens and civil society (Fung et al., 2013), as well as of social media as tools for political activism (Sandoval-Almazán \& Gil-García, 2014).

\subsection{Politics and technology}

According to this brief literature review, it should be possible to scrutinise whether an e-participation project actually aims at rendering the policy process more democratic based on the way in which technology is enacted. The two basic assumptions of this analysis are the following-

a) The political assumption. The literature suggests that, in normal circumstances, there would not be many incentives for politicians and policy-makers to render the policy process more inclusive, participatory or deliberative (Chadwick, 2008; Fung et al., 2013; $\mathrm{UN}, 2016)$. The concept of policy process is used here to generally refer to policymaking, decision-making, and, considering the warnings of Susha \& Grönlund (2012), public service design.

b) The technological assumption. The literature also suggests technological, cultural, organisational and political factors are inscribed into the enactment of technology (Cordella and Ianacci, 2010; Dawes, 2008; Holliday, 2001; Hood, 2006; Hood \& Margetts, 2007; Kraemer \& King, 1986; Rethemeyer, 2007). For the purposes of this work, this would mean that the scarcity of political incentives to render the policy process more inclusive, participatory or deliberative are embedded into technologies used for implementing e-participation schemes.

Thus, according to (a) the political and (b) the technological assumptions, in normal circumstances, it is expected that the enactment of ICTs in e-participation projects will prevent these schemes from making the policy process more inclusive, participatory or deliberative. The next section will try to find out if this holds true in the case of a 10-year old e-participation scheme in Colombia. 


\section{Methodology}

\subsection{The case study: Colombia's Urna de Cristal}

The objective of this work is to test if the idea according to which, in normal circumstances, the scarcity of incentives for politicians to make the policy process more inclusive, participatory, or deliberative is embedded into the enactment of technology holds true in the case of Colombia's Urna de Cristal (literally "Crystal Ballot Box"). This is a multimedia e-participation scheme composed of a variety of projects (commonly known as "campaigns") run by the Ministry of Information and Communications Technology of Colombia (Ministry of ICTs) since 2010.

As explained on this scheme's official website (Urna de Cristal, ca. 2018), the Ministry of ICTs carries out, often along another public agency, three different types of e-participation projects or campaigns -

- Education campaigns. The Colombian government resolves doubts and informs about a particular policy. According to the UN categorisation these strategies would be at the e-information level.

- Consultation campaigns. The Colombian government provides citizens with the opportunity to voice their opinions by answering surveys, questionnaires and more specific queries. As it is obvious, these campaigns relate to the e-consultation level.

- Influence campaigns. In this case, the members of the public may influence policy decisions. This is what the UN define as the e-decision-making level.

All these types of campaigns are conducted at both the local and national level.

This is an excellent case to test the assumptions of this work for three main reasons. Firstly, the outcomes of these initiatives are highly regarded by the Colombian government. Indeed, it has been in place for a decade, covering all the time ex-President Juan Manuel Santos was in office. Moreover, the scheme was awarded in 2017 with an honourable mention at the government-run competition "Top Management National Awards". Secondly, every campaign is deployed using different media (i.e. technologies), such as e-mail, Facebook, Twitter, Instagram, Google+, official websites, and even offline media as SMS messages and USSD surveys. Finally, this is an excellent case because there is plenty of information about it published online - the Colombian government has published many documents which makes possible to obtain fairly detailed information on each campaign.

This work will focus on the 17 e-participation projects implemented by Urna de Cristal during 2017 at the national level. This is due to data availability - there is more comprehensive and detailed data on the 2017 campaigns accessible online - and political timing - this is the last calendar year that ex-President José Manuel Santos was in office (he left the presidency in Agust 2018) and projects implemented within that period would be a good depiction of the last stage of the evolution of this scheme during his presidency. Table 1 provides an overview of the campaigns that will be studied. 
Table 1: Overview of campaigns (Urna de Cristal, 2017)

\begin{tabular}{|c|c|c|c|c|}
\hline Campaign & Days & Type & Objective & Policy status \\
\hline Colombians abroad & 120 & Consultation & $\begin{array}{l}\text { To help the government to } \\
\text { motivate Colombians living } \\
\text { abroad to fill in a form for } \\
\text { their identification }\end{array}$ & $\begin{array}{l}\text { Implementati } \\
\text { on }\end{array}$ \\
\hline $\begin{array}{l}\text { Accountability } \\
\text { Handbook }\end{array}$ & 19 & Consultation & $\begin{array}{l}\text { To find out what people think } \\
\text { of the new Accountability } \\
\text { Handbook for public agencies }\end{array}$ & Designed \\
\hline $\begin{array}{l}\text { E-consultation } \\
\text { Handbook }\end{array}$ & 45 & Consultation & $\begin{array}{l}\text { To find out what people think } \\
\text { of the E-consultation } \\
\text { Handbook }\end{array}$ & Designed \\
\hline OGP Principles & 19 & Consultation & $\begin{array}{l}\text { To further the principles of } \\
\text { the Open Government } \\
\text { Partnership (OGP) }\end{array}$ & Designed \\
\hline SPS Accountability & 16 & Consultation & $\begin{array}{l}\text { To answer questions about } \\
\text { public service delivery } \\
\text { (water, electricity, gas) }\end{array}$ & Designed \\
\hline Billing system & 56 & Consultation & $\begin{array}{l}\text { To find out what people think } \\
\text { of the new digital billing } \\
\text { system for public services }\end{array}$ & Designed \\
\hline $\begin{array}{l}\text { Justice Strategy 2017- } \\
2027\end{array}$ & 80 & Consultation & $\begin{array}{l}\text { To consult about how the } \\
\text { justice system can be } \\
\text { improved }\end{array}$ & $\begin{array}{l}\text { Design in } \\
\text { progress }\end{array}$ \\
\hline Animal Abuse & 37 & Consultation & $\begin{array}{l}\text { To consult what should be } \\
\text { included in the new animal } \\
\text { abuse regulations }\end{array}$ & $\begin{array}{l}\text { Design in } \\
\text { progress }\end{array}$ \\
\hline School Meals & 124 & Education & $\begin{array}{l}\text { To monitor a school meals } \\
\text { programme }\end{array}$ & $\begin{array}{l}\text { Implementati } \\
\text { on }\end{array}$ \\
\hline New Police Act & 206 & Education & $\begin{array}{l}\text { To inform and educate people } \\
\text { on the new Police Act }\end{array}$ & Designed \\
\hline Housing Schemes & 9 & Education & $\begin{array}{l}\text { To find out what people think } \\
\text { of the outcome of different } \\
\text { housing schemes }\end{array}$ & Designed \\
\hline $\begin{array}{l}\text { Public } \quad \text { Services } \\
\text { Platform }\end{array}$ & 7 & Education & $\begin{array}{l}\text { To consult what should be } \\
\text { included in a new platform } \\
\text { for monitoring public service } \\
\text { delivery }\end{array}$ & $\begin{array}{l}\text { Design in } \\
\text { progress }\end{array}$ \\
\hline
\end{tabular}




\begin{tabular}{|l|l|l|l|l|}
\hline Digital Documents & 18 & Education & $\begin{array}{l}\text { To inform people of the } \\
\text { benefits of the digitisation of } \\
\text { administrative procedures }\end{array}$ & Designed \\
\hline Plastic Bags & 46 & Education & $\begin{array}{l}\text { To collect feedback on the } \\
\text { new regulation on } \\
\text { rationalization of the use of } \\
\text { plastic bags }\end{array}$ & Designed \\
\hline Colombia Wins & 49 & Education & $\begin{array}{l}\text { To inform the achievements } \\
\text { of the government regarding } \\
\text { transportation, education, } \\
\text { security and anti-corruption }\end{array}$ & Designed \\
\hline Women's Day & 1 & Education & $\begin{array}{l}\text { To celebrate the International } \\
\text { Women's Day }\end{array}$ & N/A \\
\hline Mocoa Landslide & 17 & Emergency & $\begin{array}{l}\text { To keep people informed in } \\
\text { the aftermath of landslide in } \\
\text { Mocoa }\end{array}$ & N/A \\
\hline
\end{tabular}

Author's work based on Ministry of ICTs, 2017a, 2017b.

\subsection{Data}

All the information of Urna de Cristal used in this work has been retrieved from the official website of the scheme and the social media platforms used in each campaign (Urna de Cristal, ca. 2018). The main documents guiding this analysis are-

- Ejercicios de participación 2017 (Ministry of ICTs, 2017a). This is an official PDF file composed of the so-called "papers" of every e-participation project implemented by Urna de Cristal in 2017. These papers contain detailed data on each campaign.

- Ejercicios de participación nacionales (Ministry of ICTs, 2017b). This is an official spreadsheet containing quantitative information on each campaign implemented by Urna de Cristal in 2017. It also provides links to official documentation, posts on social media, etc.

\subsection{Methods}

The methodology used in this work consists in the application to Colombia's Urna de Cristal of a set of criteria developed based on the multi-dimensional framework for the evaluation of a "centralized cross-platform approach to social media exploitation by government agencies" elaborated by Ferro et al. (2013, p.362). In line with the preliminary conclusions of the literature review, Ferro and his colleagues identify three areas of evaluation: i) technological evaluation, ii) organisational innovation and diffusion evaluation, and iii) political evaluation. This section outlines the three political criteria, developed in line with the political dimension of this evaluation framework, that will be 
used to analyse if the Government of Colombia pretended to make the policy process more inclusive, participatory or deliberative while implementing Urna de Cristal.

\subsubsection{Inclusion criteria}

Technology enacted in a fashion in which a wider audience is reached would embody the intention of rendering the policy process more inclusive. This will be analysed by looking at-

- $\quad$ the number of government inputs, this is, e-mail and SMS messages sent out, posts shared online, etc. (how many people did the government try to reach?)

- the number of media used to share content with the public (what spectrum of social media users did the campaign cover? Did it narrow the digital divide?)

- the reach of each post on social media (how many people had access to the information shared by the government?)

- the length of the campaign (was the campaign running for enough time to reach as people as possible/needed?)

Additionally, citizen inputs-likes, shares, e-mails opened, answers to surveys, comments, etc. may be used to assess the effectiveness (response rate) of these initiatives. It should be noticed that this would only be a form of control since correlating people's behaviour with political intentions goes beyond the scope of this work.

\subsubsection{Participation criteria}

Technology enacted in a fashion in which it is more likely to collect feedback from the public would embody the intention of rendering the policy process more participatory. This highly depends on the opportunities provided by the government for people to provide feedback on a policy proposal or similar initiative, and, therefore, would be analysed by-

- reviewing the variety of media available to give feedback (could people provide feedback on the media of their choice?), and the length of each campaign (how much time did people have to read the information shared by the government and/or prepare their feedback? How long did the campaigns intending to collect feedback last?), and

- studying the structure of the information published or the questions made to the public (was the government really trying to collect feedback?).

Additionally, this analysis will be complemented by looking at the number of citizen interactions that can be deemed as a pertinent contribution to the goal of each campaign. Many like, shares, jokes and comments out of topic may count as citizen input for the purposes of the inclusion criteria, but cannot be considered pertinent contributions leading to a more participatory policy process. It should be noted again that this would only be a form of control since correlating people's behaviour with political intentions goes beyond the scope of this work. 


\subsubsection{Deliberation criteria}

Technology enacted in a fashion in which citizen inputs should or at least can be considered by the government would embody the intention of rendering the policy process more deliberative. This will be analysed by looking at two indicators -

- Firstly, the number of Influence campaigns, this is, those that not only aim at educating or consulting the public but also allow them to influence on policy decisions. This would be a strong indication as to what were the political intentions of the Colombian government while implementing Urna de Cristal. The more influence campaigns, the more willingness to make the policy process more deliberative.

- Secondly, the status of the policy subject of each campaign is a critical indicator of its political drivers. Put differently, timing is everything - if the policy in question has already been developed or even implemented, the opportunities for the public to influence on them would be severely restricted by design.

As mentioned above, due to data availability and political timing, the application of these three criteria will be limited to the e-participation projects embraced by Urna de Cristal in 2017 at the national level. The campaigns implemented at the local level will only be brought into the debate when strictly necessary.

\section{Findings}

\subsection{Application of the inclusion criteria}

First, the Colombian Government sent out a fair number of messages to the public as part of the nation-wide e-participation projects implemented under the umbrella of Urna de Cristal in 2017 (see Table 2). Actually, the government sent more than 1 million e-mails (12 campaigns) and 4,519,713 SMS messages (13 campaigns) to Colombian residents and citizens in this period. This represents almost all government inputs (more than a $99 \%$ of them). Even though one person can receive more than one e-mail or SMS message, these numbers are not poor for a country with a population of 50 million people (World Bank, ca. 2018). However, when these figures are compared to citizen inputs, the real problem seems to be the low response rate of government inputs. Only a $4.8 \%$ of the e-mails sent across ended up being opened. The situation of SMS messages is also dire but slightly different. Most of the time these messages were an invitation for the citizen to call for free to answer a USSD survey (these were used in 7 campaigns). These polls received 35,425 responses, this is, a number equivalent to just a $0.8 \%$ of all the SMS messages sent by the government. Moreover, half of these responses were given in the education campaign on the New Police Act. Despite all of this, the absolute value of these responses may be significant, especially when compared to the public reception of the campaigns on social media.

Table 2: Government and citizen inputs by technology (Urna de Cristal, 2017) 


\begin{tabular}{|l|l|l|}
\hline Technology & Government inputs & Citizen inputs \\
\hline Facebook & 339 & 23,475 \\
\hline Twitter & 382 & 2,706 \\
\hline Instagram & 85 & 2,394 \\
\hline Google+ & 126 & 1,974 \\
\hline E-mail & $1,058,411$ & 50,084 \\
\hline SMS/USSD & $4,519,713$ & 35,425 \\
\hline Total & $5,579,055$ & 116,058 \\
\hline
\end{tabular}

Author's work based on Ministry of ICT, 2018a; 2018b.

Second, almost every campaign used a variety of social media. All of them used Facebook and Twitter, with the only exception of the School Meals campaign which was specially designed for SMS messages. Moreover, Instagram was present in 13 campaigns and Google+ in 15.

Third, Facebook posts seemed to have had a good-enough reach but this is hard to confirm with the evidence available. Even though social media platforms were less used than e-mail and SMS messages, it should be noticed that 1 e-mail equals to 1 receiver, while 1 post may equal to a much wider audience. Then, while only 50,048 users opened (and maybe read) an e-mail, each Facebook post reached 6,721 users (and maybe readers) on average. If the campaign on the new Police Act, the most popular one, is left out of the calculus, this average number drops to below 5,000 (details are shown in Table 3). It is not entirely clear whether these are good-enough performance numbers. While 6,721 users equal to a $0.01 \%$ of the Colombian population, they also were a $5.4 \%$ of the followers of Urna de Cristal on Facebook in August 2018, and probably a larger portion of the users that were logged on during the lifespan of each post. Citizens, however, did not seem to have a considerable interest in what Urna de Cristal posted online. All citizen interactions (shares, likes, comments) on social media (Facebook + Instagram + Twitter + Google+) went up to 30,549 in 2017. This is not a particularly good number since roughly 5,000 more responses were given to the USSD surveys, and this technology was only used in 7 campaigns. The videos posted on Facebook had 130,000 more views but most of them were concentrated in one campaign - the new Police Act campaign contributed with 89,420, followed by Mocoa Landslide with 17,107, and Animal Abuse with 10,582.

Table 3: Government posts and citizen inputs on Facebook (Urna de Cristal, 2017)

\begin{tabular}{|l|l|l|l|l|}
\hline Campaign & Posts & Reach (users) & Likes, Shares & Comments \\
\hline
\end{tabular}




\begin{tabular}{|c|c|c|c|c|c|c|c|}
\hline & Total & $\mu$ & Median & $\mu$ & Median & $\mu$ & Median \\
\hline $\begin{array}{l}\text { Colombians } \\
\text { Abroad }\end{array}$ & 23 & 2,768 & 2,656 & 15 & 12 & 1.3 & 1 \\
\hline $\begin{array}{l}\text { Accountabilit } \\
\text { y Handbook }\end{array}$ & 13 & 2,560 & 2,395 & 8 & 7 & 0.9 & 1 \\
\hline $\begin{array}{l}\text { E- } \\
\text { consultation } \\
\text { Handbook }\end{array}$ & 16 & 2,830 & 2,756 & 16 & 12 & 2.8 & 2 \\
\hline $\begin{array}{l}\text { OGP } \\
\text { Principles }\end{array}$ & 17 & 4,671 & 4,173 & 57 & 47 & 15.2 & 12 \\
\hline $\begin{array}{l}\text { SPS } \\
\text { Accountabilit } \\
\mathrm{y}\end{array}$ & 7 & 5,773 & 2,563 & 60 & 17 & 7 & 5 \\
\hline $\begin{array}{l}\text { Billing } \\
\text { System }\end{array}$ & 27 & 7,656 & 6,877 & 47 & 35 & 4.3 & 3 \\
\hline $\begin{array}{l}\text { Justice } \\
\text { Strategy } \\
2017-2027\end{array}$ & 57 & 5,330 & 4,859 & 40 & 36 & 13 & 10 \\
\hline $\begin{array}{l}\text { Animal } \\
\text { Abuse }\end{array}$ & 32 & 6,257 & 4,179 & 61 & 37 & 4.5 & 3 \\
\hline $\begin{array}{l}\text { New Police } \\
\text { Act }\end{array}$ & 51 & 16,640 & 5,400 & 167 & 35 & 28 & 5 \\
\hline $\begin{array}{l}\text { Housing } \\
\text { Schemes }\end{array}$ & 6 & 5,575 & 5,699 & 130 & 44 & 23.2 & 10.5 \\
\hline $\begin{array}{l}\text { Public } \\
\text { Services } \\
\text { Platform }\end{array}$ & 6 & 5,407 & 3,634 & 30 & 30 & 5.4 & 6.5 \\
\hline $\begin{array}{l}\text { Digital } \\
\text { Documents }\end{array}$ & 15 & 4,352 & 3,192 & 10 & 7 & 0.6 & 0 \\
\hline Plastic Bags & 28 & 4,746 & 3,937 & 36 & 20 & 3.8 & 3 \\
\hline $\begin{array}{l}\text { Colombia } \\
\text { Wins }\end{array}$ & 12 & 2,374 & 2,156 & 16 & 12 & 3.4 & 2.5 \\
\hline $\begin{array}{l}\text { Women's } \\
\text { Day }\end{array}$ & 8 & 2,391 & 2,229 & 19 & 16 & 3.8 & 2.5 \\
\hline $\begin{array}{l}\text { Mocoa } \\
\text { Landslide }\end{array}$ & 20 & 6,940 & 4,513 & 83 & 18 & 3 & 2 \\
\hline
\end{tabular}

Author's work based on Ministry of ICT, 2018a; 2018b. $\mu=$ average. 
Fourth, most campaigns had a fair length. Consultation campaigns were in place for 49 days on average and Education campaigns for 57 days (65 if the Women's Day campaign is left out) - there were none Influence campaigns.

The application of the inclusion criteria suggests that the Colombian Government was interested in rendering the policy process more inclusive in most nation-wide Urna de Cristal projects during 2017. They sent out a fair number of messages to the public, almost every campaign resorted to a variety of media (including traditional media which would help to narrow the digital divide), Facebook posts seemed to be wide-reaching, and campaigns were in place for 7-9 weeks in average. Nonetheless, most government inputs were SMS messages, and the data on the implementation of the campaigns on Facebooks is open to interpretation. Then, a more precise quantitative analysis, taking into account budget constraints (not considered here), and data on the online collaboration of other government departments (not available), as well as the reach of social media other than Facebook (not available), may help to draw a more solid conclusion in this regard.

\subsection{Application of the participation criteria}

While the application of the inclusion criteria showed that the Colombian government resorted to a variety of media to share content, a review of this evaluation criterion shows that the reception of feedback was largely centralised on Urna de Cristal's official website. Many Facebook posts, tweets, SMS messages, e-mails, and USSD Surveys invited people to provide their feedback on this website, namely on online "topical debates" or "discussion forums".

The performance numbers of both types of web sections were very poor. Considering the 11 campaigns that implemented "topical debates" web sections, there were only 1,181 comments. The Plastic Bags campaign contributed with 862 of them, so the remaining 10 campaigns only received a total of 319 comments. Moreover, although many of these comments were proper feedback, a large proportion of them was composed of questions, complaints and social criticism - not pertinent contributions to the corresponding policy. The figures of the "discussion forums" were even worse. These were embraced by the Housing Schemes and the e-Consultation Handbook campaigns. In the first case, there were only 21 posts - all of them were questions for the government (e.g., what can I do to buy a house if I have a low income?) rather than feedback to any specific policy proposal. The case of the e-Consultation Handbook is slightly different. The government directly asked people how they think they could collaborate with the government in passing new regulations and, therefore, citizens provided feedback instead of making questions. Alas, only 4 people did so.

USSD surveys may have received more than 35,000 responses, but the questions of these campaigns were not aiming at receiving any useful feedback from the public. They were just used to inform them about a policy (e.g.," are you aware of the new faults regulated by the Police Act coming soon into effect?") or to keep people informed of a government policy already designed (e.g., "what is more incorrect: a) jumping a queue, b) cheating on an exam or c) buying illegal copies of a book?"; example taken from the Justice Strategy 2017-2027 campaign). This is true even in those projects whose formal purpose was to know what people thought about a policy (e.g., the Plastic Bags cam- 
paign) or to design a new policy (e.g., the Animal Abuse campaign). The revision of every government question made on these surveys in 2017, showed that not even one of them was structured in a way that could allow people to provide pertinent feedback on a policy proposal.

On social media, the situation was slightly more favourable. The government clearly asked for proposals on Facebook, Twitter, Google+ or Instagram in four campaigns: Public Service Platform, Justice Strategy 2017-2027, Animal Abuse and OGP Principles. However, the opportunities for people to prepare and give feedback were very restricted. The campaign for creating a new platform for allowing people to monitor the delivery of public services (gas, electricity, water) lasted only 6 days, in which it received 27 comments on Facebook, three on Twitter, and just one on Google+. The campaign on animal abuse lasted more than a month but almost every government post was an invitation to visit the "topical debate" website of this campaign (a "pull strategy"), where 97 people left a comment-many of them pertinent contributions though. The campaign to develop a new strategy for the justice system had similar results with just 80 comments on its corresponding webpage, while the campaign promoting the OGP principles only got 27 . These figures contrast with the performance of these two campaigns on Facebook, where they received 13 and 15.2 comments on average per post, respectively.

The application of the participation criteria suggests that the Colombian Government did not have intentions to render the policy process more participatory as opportunities for providing feedback were very limited. First, just a few campaigns were really looking for citizen feedback in any way, shape or form. Indeed, the SPS Accountability and the Housing Schemes campaigns went so far as to only allowing people to ask questions to the government but without any real chance of challenging its policy proposals. Second, people usually could not choose the media of their preference to provide feedback and needed to take several steps before being able to do it since its reception was centralised on an official webpage-posting on Facebook or other social media was not enough. Third, a deeper analysis of the length of each campaign showed that the duration of two of the four campaigns intended, at least on paper, to collect pertinent feedback was clearly insufficient to achieve this goal (the Public Service Platform campaign lasted 6 days; and the OGP Principles just 19) and, therefore, the fact that they asked for proposals was not enough to make the policy process more participatory. The scarcity of pertinent contributions on the official website is coherent with the existence of these barriers.

\subsection{Application of the deliberation criteria}

The application of the deliberation criteria to the nation-wide Urna de Cristal projects in 2017 shows that there is practically no evidence of any intention of the Colombian government of making the policy process more deliberative. Firstly, the government did not carry out any Influence campaign at the national level. This was also the tendency at the local level- amongst 20 campaigns, there were 15 Education campaigns, 5 Consultation campaigns and none Influence campaign.

Secondly, the Colombian government was clearly reluctant to include citizen feedback in the design of new policies. The subject matter of 10 of the 17 campaigns was a policy already designed or implemented - the only intention of the government would have been to inform citizens of the potential benefits of such policies. The new Accountability Handbook campaign, for instance, was 
framed as a consultation project, but its only purpose was to promote the new government guidelines on this issue. The government only sought for some form of citizen collaboration in three cases: i) the development of the Justice Strategy 2017-2020, ii) the passing of new regulation on animal abuse, and iii) the creation of a platform for supervising public service delivery. However, as the analysis of the participation criteria showed, people's opportunities to provide feedback on these policies were severely constrained. From the remaining four campaigns, two were used to help the government to implement a policy (Colombians Abroad and School Meals) and the other two were not even related to specific policies - one was a case of crisis management (Mocoa Landslide) and the other a "commemoration" project (Women's Day).

The evidence suggests that the Colombian government had very limited intentions of rendering the policy process more deliberative. There were no influence campaigns in 2017, only three campaigns embraced policies in the process of being designed, and one of these related to public service delivery and lasted less than a week. All of this leads to call into question the nature of Urna de Cristal as an e-participation scheme - the programme looked more like a communication strategy during the year studied. Actually, from the 10 campaigns on policies already designed or implemented, two of them had the clear intention of increasing government's domestic legitimacy. This is the case of the campaign aiming at promoting the principles of the Open Government Partnership and, obviously, of the campaign to inform the achievements of the government regarding transportation, education, security and anti-corruption (Colombia Wins). Similarly, the campaigns on Housing Schemes, the Accountability Handbook, and the e-Consultation Handbook were intended to share with the general public "positive" measures the government had already taken.

\section{Conclusion}

The literature review allowed us to draw two preliminary conclusions (see Section 2.3.). Firstly, in normal circumstances, political authorities would not have many incentives to make the policy process more democratic, this is, more inclusive, participatory or deliberative. Secondly, politics would not only affect how technological solutions are deployed but would also be embedded into them an open government data portal containing JSON and CVS files would reflect the political intention of opening government and creating spaces of public-private collaboration, while a similar portal that only shares PDF files would not reflect such motivations. Therefore, it should be expected that, in normal circumstances, the enactment of technology-enabled participation projects will prevent these schemes from making the policy process more inclusive, participatory or deliberative.

The objective of this work was to determine if these preliminary conclusions drawn from the literature held true in the case of Colombia's Urna de Cristal, a multimedia e-participation scheme composed of a variety of projects (commonly known as "campaigns") run by the Ministry of Information and Communications Technology. With this aim, a series of criteria were drawn and adapted from a multi-dimensional framework for the evaluation of centralized cross-platform approaches to social media exploitation by government agencies developed elsewhere. Then, these criteria - inclusion, participation, and deliberation - were applied to the nation-wide projects implemented under the umbrella of this scheme during 2017. 
The evidence analysed suggested that the Colombian government had scant political incentives to make the policy process more democratic during the implementation of Urna de Cristal. Indeed, there is little evidence of any intention of rendering the policy process more participatory or deliberative - there were limited chances for people to provide feedback, information campaigns were disguised as consultation campaigns, the reception of proposals was generally centralised on an official website, most of the campaigns dealt with policies already designed, a couple of them tried to legitimise the work of the government, and a none influence campaign was implemented at local and national levels. Nevertheless, some data suggested that there was an intention of making the policy process more inclusive. Although this evidence is not conclusive, this might be coherent with the framing of this e-participation scheme as a communication strategy. Thus, the Colombian government would have been willing to keep people informed of certain issues, namely of policies already implemented, but it would have also prevented them from providing feedback and influencing decision making. This may be used as a working assumption in future academic studies or policy evaluations of this scheme.

This case study has, of course, certain limitations. First, a more comprehensive assessment may be required - this work only examined one of the years that Urna de Cristal has been in place, and did not take into account local campaigns. Second, this case study may be complemented by a more in-depth qualitative analysis. For instance, the deliberation criteria could be better applied if politicians, public servants, and even citizens were interviewed, or policy outputs were compared to citizen proposals. Third, the use of more rigorous quantitative methods may help to build stronger conclusions with regards to the inclusion criteria. Fourth, alternative explanations should be explored as well. Maybe Urna de Cristal does not have the capacity to implement campaigns that make policy making more inclusive, participatory or deliberative; maybe the official data available online is not reflecting the internal (or even invisible) work of the team in charge of implementing each campaign; or maybe these civil servants did not have the experience, skills or training required to deploy large-scale e-participation projects.

However, despite these limitations, the findings of this work are consistent with the proposition according to which the lack of political incentives to make the policy process more democratic is likely to be embedded into the enactment of technology. Indeed, the social media platforms, messaging services, and webpages utilised by the Colombian government to implement e-participation projects in 2017 at the national level largely reflected their intention of preventing the public from participating and having influence on the policy process. This interplay between platforms, social media, policy status, government intentions, types of campaign, and other inputs should not be disregarded in future research on e-participation and e-democracy.

\section{References}

Abu-Shanab, E. A. (2015). Reengineering the open government concept: An empirical support for a proposed model. Government Information Quarterly, 32(4), 453-463. DOI: http://dx.doi.org/10.1016\%2Fj.giq.2015.07.002

Ahn, M. J., \& Bretschneider, S. (2011). Politics of e-government: E-government and the political control of bureaucracy. Public Administration Review, 71(3), 414-424. DOI: http://dx.doi.org/10.1111\%2Fj.15406210.2011.02225.x 
Becker, T. (1998). 'Governance and electronic innovation': A clash of paradigms. Information, Communication and Society, 1(3), 339-343. DOI: https:// doi.org/10.1080/13691189809358973

Bellamy, C. \& Taylor, J. (1998). Governing in the information age. Buckingham and Philadelphia: Open University Press.

Bertot, J., Jaeger, P. \& Grimes, J. (2010). Using ICTs to create a culture of transparency: E-government and social media as openness and anti-corruption tools for societies. Government Information Quarterly, 27(3), 264-271. DOI: https://doi.org/10.1016/j.giq.2010.03.001

Björklund, F. (2016). E-government and moral citizenship: the case of Estonia. Citizen Studies, 20(6-7), 914-931. DOI: https://www.tandfonline.com/doi/full/10.1080/13621025.2016.1213222

Bracken, M. (2015). Government as a Platform: the next phase of digital transformation [Blog post]. Retrieved March 29, 2018, from https://gds.blog.gov.uk/2015/03/29/government-as-a-platform-the-next-phaseof-digital-transformation/

Buffat, A. (2015). Street-level bureaucracy and e-government. Public Management Review. 17(1), pp.149-161. DOI: https://doi.org/10.1080/14719037.2013.771699

Cordella, A., \& Iannacci, F. (2010). Information systems in the public sector: The e-Government enactment framework. The Journal of Strategic Information Systems, 19(1), 52-66. DOI:

https://doi.org/10.1016/j.jsis.2010.01.001

Chadwick, A. (2008). Web 2.0: New challenges for the study of e-democracy in an era of informational exuberance. I/S: A Journal of Law and Policy for the Information Society, 5(1), 9-41.

Chadwick, A. (2011). Explaining the failure of an online citizen engagement initiative: The role of internal institutional variables. Journal of Information Technology \& Politics, 8(1), 21-40. DOI:

https://doi.org/10.1080/19331681.2010.507999

Dawes, S. (2008). The evolution and continuing challenges of e-governance. Public Administration Review, 68(s1): 86-102.

van de Donk, W., Snellen, I., \& Tops, P. (1995). Orwell in Athens. A Perspective on Informatization and Democracy. In W. van de Donk, I. Snellen and P. Tops (Eds.), Orwell in Athens. A Perspective on Informatization and Democracy (pp.1-11). Amsterdam, Oxford, Tokyo, Washington: IOS Press.

Dunleavy, P., Margetts, H., Bastow, S., \& Tinkler, J. (2006). New public management is dead-long live digital-era governance. Journal of Public Administration Research and Theory, 16(3): 467-494. DOI: https://doi.org/10.1093/jopart/mui057

Dunleavy, P., \& Margetts, H. Z. (2013). The second wave of digital era governance: quasi-paradigm for government on the Web. Philosophical Transactions of The Royal Society a Mathematical Physical and Engineering Sciences, 371(1987), 1-17. DOI: https://doi.org/10.1098/rsta.2012.0382

Dwivedi, Y., Weerakkody, V. \& Janssen, M. (2012). Moving towards maturity: challenges to successful e-government implementation and diffusion. ACM SIGMIS Database: the DATABASE for Advances in Information Systems, 42(4), 11-22.

Eriksson, K. (2005). Foucault, Deleuze, and the Ontology of Networks. The European Legacy, 10(6), 595-610. DOI: https://www.tandfonline.com/doi/full/10.1080/10848770500254118 
Ferro, E., Loukis, E. N., Charalabidis, Y., \& Osella, M. (2013). Policy making 2.0: From theory to practice. Government Information Quarterly, 30(4), 359-368. DOI: http://dx.doi.org/10.1016\%2Fj.giq.2013.05.018

Foucault, M. (1980). Power/Knowledge: Selected Interviews and Other Writings, 1972-1977. New York: Pantheon.

Fountain, J. (2001). Building the Virtual State: Information Technology and Institutional Change. Washington, DC: Brooking Institution Press.

Fung, A., Russon Gilman, H., \& Shkabatur, J. (2013). Six models for the internet+politics. International Studies Review, 15(1), 30-47. DOI: https://doi.org/10.1111/misr.12028

Gandy, O. (1989). The surveillance society: information technology and bureaucratic social control. Journal of Communication, 39(3), 61-76. DOI: https:// doi.org/10.1111/j.1460-2466.1989.tb01040.x

Girish, J., Williams, C. B., \& Yates, D. J. (2014). Predictors of on-line services and e-participation: A cross-national comparison. Government Information Quarterly, 31(4), 526-533. DOI: http://dx.doi.org/10.1016\%2Fj.giq.2014.07.005

Heeks, R. (1999). Reinventing government in the information age: International practice in IT-enabled public sector reform. London: Routledge.

Heeks, R., \& Davies, A. (1999). Different approaches to information age reform. In R. Heeks (Ed.), Reinventing government in the information age: International practice in IT-enabled public sector reform. London: Routledge.

Heeks, R. (2007). Understanding e-Government project trajectories from an actor-network perspective. European Journal of Information Systems, 16(2), 165-177. DOI: https:/ / orsociety.tandfonline.com/doi/full/10.1057/palgrave.ejis.3000676\#.X2NkjWhKiUk

Holliday, I. (2001). Steering the British State in the Information. Government and Opposition. 36(3), 314-330. DOI: https://doi.org/10.1111/1477-7053.00068

Hood, C. (2000). Where the state of the art meets the art of the state: traditional public-bureaucracy controls in the information age. International Review of Public Administration, 5(1), 1-12. DOI: https://doi.org/10.1080/12294659.2000.10804939

Hood, C. (2006). The Tools of Government in the Information Age. In R. Goodin, M. Moran, and M. Rein (Eds.), The Oxford Handbook of Public Policy (pp.469-481). Oxford: Oxford University Press.

Hood, C. \& Margetts, H. (2007). Tools of Government in the Digital Age. Houndmills and New York: Palgrave Macmillan.

Introna, L., Hayes, N., \& Petrakaki (2009). The Working Out of Modernization in the Public Sector: The Case of an E-government Initiative in Greece. International Journal of Public Administration, 33(1), 11-25. DOI: https://www.tandfonline.com/doi/full/10.1080/01900690903188750

Keyser, R. (2017). Blockchain: A Primer for Governments [Blog Post]. Retrieved February 6, 2018, from http://www.viewpointcloud.com/blog/government-technology/blockchain-governments-primer/

Kim, H., Pan, G., \& Pan, S. (2007). Managing IT-enabled transformation in the public sector: A case study on e-government in South Korea. Government Information Quarterly, 24(2), 338-352. DOI:

http://dx.doi.org/10.1016\%2Fj.giq.2006.09.007 
Kraemer, K.L. \& King, J.L. (1986). Computing and public organizations. Public Administration Review, pp.488496. DOI: https://www.jstor.org/stable/975570

Layne, K. \& Lee, J. (2001). Developing fully functional E-government: A four stage model. Government Information Quarterly, 18(2), 122-136.

Luna-Reyes, L., \& Gil-Garcia, J. (2014). Digital government transformation and internet portals: The co-evolution of technology, organizations, and institutions. Government Information Quarterly, 31(4), 545-555. DOI: http://dx.doi.org/10.1016\%2Fj.giq.2014.08.001

Macintosh, A. (2004). Characterizing e-participation in policy-making. In 2004. Proceedings of the 37th Annual Hawaii International Conference on System Sciences, 5-8 January 2004, Big Island, Hawaii, US. Retrieved March 2, 2018, from https:/ / doi.org/10.1109/HICSS.2004.1265300

Margetts, H. (1999). Information technology in government: Britain and America. London and New York: Routledge.

Margetts, H. (2003). Electronic Government: A Revolution? In G. Peters and J. Pierre (Eds.), Handbook of Public Administration (pp.366-736). London: SAGE Publications

Mayer-Schönberger, V., \& Cukier, K. (2013). Big Data. A revolution that will transform how we live, work, and think. Boston and New York: Eamon Dolan Book; Houghton Mifflin Harcourt.

Medaglia, R. (2012). eParticipation research: Moving characterization forward (2006-2011). Government Information Quarterly, 29(3), 346-360. DOI: http:// dx.doi.org/10.1016\%2Fj.giq.2012.02.010

Meijer, A. (2008). E-mail in government: Not post-bureaucratic but late-bureaucratic organizations. Government Information Quarterly, 25(3), 429-447. DOI: http:/ / dx.doi.org/10.1016\%2Fj.giq.2007.05.004

Mergel, I. (2013a). Social media adoption and resulting tactics in the US federal government. Government Information Quarterly, 30(2), 123-130. DOI: https://doi.org/10.1016/j.giq.2012.12.004

Mergel, I. (2013b). A framework for interpreting social media interactions in the public sector. Government Information Quarterly, 30(4), 327-334. DOI: http://dx.doi.org/10.1016\%2Fj.giq.2013.05.015

Ministry of Information and Communications Technology (2017a). Ejercicios de participación 2017. Bogotá: Urna de Cristal. Retrieved February 10, 2018, from http://www.urnadecristal.gov.co/ejercicios-participacion-urna-2017

Ministry of Information and Communications Technology (2017b). Ejercicios de participación nacionales. Bogotá: Urna de Cristal. Retrieved February 5, 2018, from https://goo.gl/czF9JK

Mossberger, K., Wu, Y., \& Crawford, J. (2013). Connecting citizens and local governments? Social media and interactivity in major US cities. Government Information Quarterly, 30(4), 351-358. DOI: http://dx.doi.org/10.1016\%2Fj.giq.2013.05.016

Norris, D.F. \& Moon, M.J. (2005). Advancing e-government at the grassroots: Tortoise or hare?. Public Administration Review, 65(1), 64-75. DOI: https://doi.org/10.1111/j.1540-6210.2005.00431.x

O'Reilly, T. (2011). Government as a Platform. Innovations: Technology, Governance, Globalization, 6(1), 13-40. DOI: https://doi.org/10.1162/INOV_a_00056 
Obama, B. (2009) Memorandum on transparency and open government. Retrieved March 1, 2018, from https://obamawhitehouse.archives.gov/open/documents/open-government-directive

OECD (2001). Citizens as Partners. OECD Handbook on Information, Consultation and Public Participation in Policy-Making. Paris: OECDpublishing. Retrieved September 16, 2020, from https:/ / www.oecd-ilibrary.org/governance/citizens-as-partners_9789264195578-en

OECD (2014). Recommendation of the Council on Digital Government Strategies. Public Governance and Territorial Development Directorate. Paris: OECD. Retrieved March 10, 2018, from https://www.oecd.org/gov/digital-government/recommendation-on-digital-government-strategies.htm

Ølnes, S., Ubacht, J. \& Janssen, M. (2017). Blockchain in government: Benefits and implications of distributed ledger technology for information sharing. Government Information Quarterly, 34 (3), 355-364. DOI: https://doi.org/10.1016/j.giq.2017.09.007

Orlikowski, W. (2000). Using Technology and Constituting Structures: A Practice Lens for Studying Technology in Organizations. In Ackerman, M., Halverson, C., Erickson, T., y Kellogg, R. (Eds.) Resources, CoEvolution and Artifacts Theory in CSCW (pp.255-305). London: Springer.

Orszag, P. (2009). Open government directive. Memorandum for the Heads of Executive Departments and Agencies. Retrieved March 1, 2018 from: https:/ / obamawhitehouse.archives.gov/the-press-office/transparencyand-open-government

Osborne, D. \& Gaebler, T. (1992). Reinventing government: How the entrepreneurial spirit is transforming government. Harmondsworth: Penguin Books.

Panopoulou, E., Tambouris, E., \& Tarabanis, K. (2014). Success factors in designing eParticipation initiatives. Information and Organization, 24(4), 195-213. DOI: http://dx.doi.org/10.1016\%2Fj.infoandorg.2014.08.001

Rethemeyer, R., 2007. Policymaking in the age of internet: Is the internet tending to make policy networks more or less inclusive? Journal of Public Administration Research and Theory, 17(2), 259-284. DOI: https://doi.org/10.1093/jopart/mul001

Sandoval-Almazán, R. \& Gil-García, J.R. (2014). Towards cyberactivism 2.0? Understanding the use of social media and other information technologies for political activism and social movements. Government Information Quarterly, 31(3), 365-378. DOI: http://dx.doi.org/10.1016\%2Fj.giq.2013.10.016

Sanford, C., \& Rose, J. (2007). Characterizing eparticipation. International Journal of Information Management, 27(6), 406-421. DOI: http://dx.doi.org/10.1016\%2Fj.ijinfomgt.2007.08.002

Scholl, H. (2005). Organizational transformation through e-government: myth or reality? In M. Wimmer, R. Traunmueller, A. Grönlund, and K. Andersen (Eds.), Proceedings of the 4th International Conference, EGOV 2005, August 22-26, 2005 (pp. 1-11). Copenhagen, Denmark: Springer.

Scottish Parliament (1998). Shaping Scotlands's Parliament. Report of the Consultative Steering Group on the Scottish Parliament. Scotland. Retrieved September 16, 2020, from https://www.parliament.scot/PublicInformationdocuments/Report_of_the_Consultative_Steering_Group.pdf

Solove, D. (2001). Privacy and power: Computer databases and metaphors for information privacy. Stanford Law Review, 53(6), 1393-1462. 
Susha, I., \& Grönlund, Å. (2012). eParticipation research: Systematizing the field. Government Information Quarterly, 29(3), 373-382. DOI: http://dx.doi.org/10.1016\%2Fj.giq.2011.11.005

Sæbø, Ø., Rose, J., \& Flak, L. (2008). The shape of eParticipation: Characterizing an emerging research area. Government Information Quarterly, 25(3), 400-428. DOI: http://dx.doi.org/10.1016\%2Fj.giq.2007.04.007

UK Cabinet Office (1999). Modernizing Government, White Paper. Retrieved on March 30, 2018, from https://api.parliament.uk/historic-hansard/westminster-hall/1999/dec/09/modernising-government-white-paper

UK Cabinet Office (2017). Government Transformation Strategy. Retrieved on March 30, 2018, from https://www.gov.uk/government/publications/government-transformation-strategy-2017-to2020/government-transformation-strategy

United Nations (2016). E-Government Survey 2016. E-Government in support of sustainable development. New York. Retrieved January 25, 2018, from https://www.un.org/development/desa/publications/2016-egovernment-survey.html

Urna de Cristal (ca. 2018). Open Government Portal of Colombia: Urna de Cristal. Retrieved January 25, 2018, from http://www.urnadecristal.gov.co

Vintar, M. (1995). Information of Public Administration as an Instrument of Change to a More Democratic Society. In W. van de Donk, I. Snellen and P. Tops (Eds.), Orwell in Athens. A Perspective on Informatization and Democracy (pp.97-107). Amsterdam, Oxford, Tokyo, Washington: IOS Press.

Weerakkody, V., Janssen, M. \& Dwivedi, Y. (2011). Transformational change and business process reengineering (BPR): Lessons from the British and Dutch public sector. Government Information Quarterly, 28(3), pp.320328. DOI: http://dx.doi.org/10.1016\%2Fj.giq.2010.07.010

West, D., (2004). E-government and the transformation of service delivery and citizen attitudes. Public Administration Review, 27(4), 187-198.

Whyte, A. \& Macintosh, A. (2004). Transparency and teledemocracy: issues from an 'e-consultation'. Journal of Information Science, 64(1), 15-27.

Winner, L. (1999). Do artifacts have politics? In D. MacKenzie and J. Wajcman (Eds.), The Social Shaping of Technology (2nd ed.) (pp. 28-40). Buckingham and Philadelphia: Open University Press.

Wong, W. \& Welch, E. (2004). Does e-government promote accountability? A comparative analysis of website openness and government accountability. Governance, 17(2), 275-297. DOI: https://doi.org/10.1111/j.14680491.2004.00246.x

World Bank (ca. 2018). World Bank Open Data, population total, Colombia. Retrieved March 29, 2018, from https://data.worldbank.org/indicator/SP.POP.TOTL?locations=CO

Zheng, Y., Schachter, H. L., \& Holzer, M. (2014). The impact of government form on e-participation: A study of New Jersey municipalities. Government Information Quarterly, 31(4), 653-659. DOI: http://dx.doi.org/10.1016\%2Fj.giq.2014.06.004

Zheng, Y. (2017). Explaining Citizens' E-Participation Usage: Functionality of E-Participation Applications. Administration \& Society, 49(3), 423-442. DOI: https:/ / doi.org/10.1177\%2F0095399715593313 
Zolotov, M. N., Oliveira, T., \& Casteleyn, S. (2018). E-participation adoption models research in the last 17 years: A weight and meta-analytical review. Computers in Human Behavior, 81, 350-365. DOI:

https://doi.org/10.1016/j.chb.2017.12.031

\section{About the Author}

\section{César Abusleme}

César has worked as policy adviser for Chile's Justice Modernisation and Management Division (2013-2015) and Legal Coordinator of Chile's Public Sector Modernisation Programme run by the Ministry of Finance and the Inter-American Development Bank (2015-2017). He has also served in the UK Government (2019-2020) and permanently contributes to the work of University of Chile's Public Systems Centre (2018-2020). He holds a law degree from the University of Chile and a MSc in Public Policy and Administration from the London School of Economics. His main research interests are the politics of the digital, technology enactment, and open government. 